Summer 2003

\title{
From Reluctant Champion to Development Ringmaster: Managing the Expanding Mission of the World Bank
}

Jane Rueger

Indiana University School of Law

Follow this and additional works at: https://www.repository.law.indiana.edu/ijgls

Part of the Banking and Finance Law Commons, and the International Law Commons

\section{Recommended Citation}

Rueger, Jane (2003) "From Reluctant Champion to Development Ringmaster: Managing the Expanding Mission of the World Bank," Indiana Journal of Global Legal Studies: Vol. 10 : Iss. 2 , Article 7.

Available at: https://www.repository.law.indiana.edu/ijgls/vol10/iss2/7

This Note is brought to you for free and open access by the Law School Journals at Digital Repository @ Maurer Law. It has been accepted for inclusion in Indiana Journal of Global Legal Studies by an authorized editor of Digital Repository @ Maurer Law. For more information, please contact rvaughan@indiana.edu.

\section{$\Psi$}

JEROME HALL LAW LIBRARY

INDIANA UNIVERSITY

Maurer School of Law
Blooming ton 


\title{
From Reluctant Champion to Development Ringmaster: Managing the Expanding Mission of the World Bank
}

\author{
Jane Rueger* \\ INTRODUCTION
}

In the last decade, the World Bank has catapulted from relative obscurity in its work to alleviate global poverty to centrality in the latest controversies over development, economic interdependence, and the global economy. Since its inception at the Bretton Woods Conference in 1944, the Bank has attempted to assist poor countries in developing the infrastructure they need to prosper in the world economy. The Bank's original mission was based on pure economic and macroeconomic reform. Through its experience in implementing this mission, however, the Bank has learned more about the nature of development and the many and various inputs necessary to achieve it. As a result, the Bank's mission has broadened significantly.

"There is probably nothing in this world more political than money." After the Cold War was won by the proponents of free trade principles, the political spotlight fell upon the World Bank as the premier multilateral institution devoted to international aid. As understanding about the nature of development grew, developed countries and NGOs increased pressure on the Bank to expand its mission to include not only macroeconomic reform, but also reform in other social and political arenas such as human rights, protection of the environment and cultural heritage, and establishment of legal institutions. At the same time, the Bank's own difficult experience further motivated it to expand its mission to accommodate these new areas of development assistance.

Greater pressure from developed countries such as the United States and the swift expansion of the World Bank's mission have made the Bank's policies a focal point for criticism and discussion about the direction of international aid

* J.D. Candidate, 2003, Indiana University School of Law-Bloomington; M.B.A. Candidate, 2003, Kelley School of Business, Indiana University-Bloomington; B.A. Political Science, 1999, Wellesley College. Many thanks to my family and friends for their boundless support.

1. Lars Schoultz, Politics, Economics, and U.S. Participation in Multilateral Development Banks, 36 INT'L Org. 537, 574 (1982). 
in development. Some critics find that the World Bank has strayed too far from its macroeconomic underpinnings, and should rein itself in to focus on the areas of its original core competencies. Others, noting the rather dismal record of World Bank assistance based solely on economic kinds of reform, believe that the Bank necessarily must expand its function to be of any use at all to the global community; these observers suggest that the Bank continue on its path toward a "holistic" approach to development and poverty reduction.

The questions facing the World Bank today are not new. Though an institution of a wholly different character, the British East India Company (the Company) faced many of the same organizational problems, transforming from a generally ignored conglomeration of merchants seeking profit in the spice trade into the British Empire's administrative agency in India. In its rise to prominence and later its decline, the Company became a key figure in the imperialist drive toward colonialism in the seventeenth and eighteenth centuries, and has become a well-known symbol for the prevailing mercantilist thought of the time. Soon after its beginnings as one of several private European trade conglomerates formed to explore the spice trade in the East Indies, the Company came under enormous pressure from the British government to compete with other European trade companies for trade routes and political influence in Asia. Over the Company's two hundred year existence, the British Empire and prevalent imperialist thought pushed the Company to expand its mission to fit the Empire's colonial goals, until, its mission expanded beyond manageable bounds, the Company ceased to be a trading company at all. Finally, the British Empire molded the Company into an administrative agent for the Empire's colonial aspirations in India.

Expansion of the Company's mission, driven by the ideological thrust of imperialism and the prevailing political economic theory of mercantilism, became both necessary for its survival and also the reason for its transformation into a bloated administrative agency. The World Bank potentially faces a similar dilemma. Having started as a bank concerned with purely economic reform, the Bank has been pushed by developed countries and NGOs to address and be accountable for numerous humanitarian concerns involved in its loan projects. Though the Bank has learned over the years that the humanitarian aspects of development aid must be addressed to bring about meaningful change, the Bank risks expanding its mission beyond manageable limits by championing these numerous and potentially conflicting causes in development. 
This article will analyze the history and development of both the Company and the World Bank, and from the comparison will draw an important lesson for the World Bank: though some expansion of its mission may in current circumstances be necessary for its continued relevance, over-expansion beyond the Bank's capabilities will be destructive to the organization itself, and will ultimately undermine its effectiveness in assisting development. Part I begins with a brief history of the Company, and describes its gradual expansion of mission from a loosely organized merchant venture to the agent of military control and territorial governance in India. Part II describes the World Bank's shifting development policy since its inception, and draws parallels between the Bank's current mission dilemma and the organizational factors that led to the collapse of the Company. Finally, Part III evaluates three current recommendations for the future direction of the World Bank.

\section{The British East India Company}

Despite differences in purpose and organization, the Company shares a similar background with the World Bank in that both began with a relatively narrow scope of purpose which expanded over time due to political and ideological pressures. Though the Company initially preferred not to replace indigenous rule with colonial power in pursuit of trade, it faced increasing pressure from the European powers to do so. Eventually the Company succumbed and was ultimately reformed into a British administrative agency in India. This part discusses the pressures placed on the Company and outlines three major phases in the development of the Company's purpose: its initial strictly mercantile purpose, its gradual expansion through militarization and territorial conquest, and finally its decline into the administration of India.

In the fifteenth and sixteenth centuries, Europeans began to voyage and make territorial discoveries around the world, and to stake claims to those new discoveries for their homelands. Spain and Portugal led the chase to the spiceproducing East Indies, maintaining that a Papal decree gave them sole right to use the two known trade routes. ${ }^{2}$ Not willing to be left behind, England searched for its own route to the Indies. When a viable third route failed to

2. John Keay, The Honorable Company: A History of the English East India Company 8 (1991). 
materialize, the English relied upon new political and ideological theories of freedom of trade to support their own right to trade abroad:
"[they harbored] a fundamental conviction-that somehow or other a share of world trade would nonetheless fall to the English. To the Tudor merchant-adventurer freedom of trade was much like freedom of conscience.... [J]ust as Rome's presumptuous claims to a monopoly of Christian truth and authority were no longer acceptable, so Madrid's claim to the treasures of the Amer- icas and Lisbon's to the trade of the Indies... were seen as "insolencyes."

Spain and Portugal, united at this time under a single monarch, intensified England's desire to gain access to the Indies by severely restricting the availability of spices to English traders in Europe. This move relieved the English of any obligation that they might have felt under the traditional Anglo-Portuguese alliance to utilize Portuguese trade routes. ${ }^{4}$ Moreover, with heavy mercantilist pressure to export British goods around the world, the English felt justified, both by ideology and customary international law, to make the Portuguese routes to the East Indies "fair game" for their own merchants.

The English Crown had greater interest in developing its North American and Caribbean holdings, however, and did not want to spare the expense of exploring the Indies directly. ${ }^{5}$ Therefore, on December 31,1600 , the Company received its first charter under the name "The Company of Merchants of London trading into the East Indies." The name was appropriate, because under this initial charter the Company did not have the right to hold overseas territories, but was given exclusive trading rights in the region. ${ }^{7}$ The Company began, only a step away from the medieval-style guild, as a loose grouping of English

3. Id. at 9 .

4. Id. at 10 .

5. D.K. Bassett, Early English Trade and Settlement in Asia, in 4 The East India Company 2-3 (Patrick Tuck ed., 1998).

6. KeAY, supra note 2, at 9.

7. The Company, therefore, accepted allegiances from spice-producers on behalf of the English Crown, and throughout the early seventeenth century, Company emissaries introduced themselves as "the King of England's Embassadour." Id. at 5, 77. 
merchants who invested in each voyage individually, taking profits from each individual voyage in return. ${ }^{8}$ Two types of investors materialized: passive investors, from any social class, who were interested solely in quick and substantial profits; and more active investors, mostly wealthy merchants, who were interested in the Indies trade itself and saw investment in the Company as a long term prospect. ${ }^{9}$ The management of the Company's affairs was accordingly divided among two corresponding bodies: the General Court, which gave the passive investors general voting rights; and the Court of Committees, consisting of the Governor, Deputy Governor, and twenty-four directors, all of whom were merchants and were elected by the General Court to run the day-to-day operations of the Company. ${ }^{10}$

Investors in the Company were united in pursuit of economic profits. As evidenced by the first Royal Charter, territorial expansion in the Company's name was not on its agenda. A new charter written in 1609 , however, renewed the Company's monopoly rights to trade in the Indies and indicated the Crown's support for its endeavors. This development further demonstrated that the Crown might, in the future, use the Company for political purposes. "Despite this ominous sign, the Company was initially left to manage its affairs as it saw fit, and at that time it did not follow the examples set by other Europeans in the Indies. For instance, the Company did not construct defensive forts in the Indies, but only small trading outposts, called factories, for collecting spices before transit to Europe. These factories were not built for colonial or political purposes, but had the primary goal of withholding spices from the market in order to smooth out price fluctuations that occurred whenever a new shipment arrived in London. This in turn smoothed the Company's profits over the year. ${ }^{12}$

More importantly, the Company did not espouse the strong-arm tactics of its Dutch rivals of the same name. Instead, it attempted first to work from

\footnotetext{
8. Id. at $27-28$.

9. Id. at 25 .

10. Id. at 26 .

11. Id. at 39 .

12. Id. at 21. It is important to note, however, that at least part of the Company's reluctance to develop a military presence initially was due to the large expense in arranging and maintaining warships and defensive structures; as a very new and untried adventure the Company could not afford to build more than factories, even if it had wished to do so. Bassett, supra note 5, at 3; see also Peter Marshall, British Expansion in India in the Eighteenth Century: A Historical Revision, in 5 The East India Company, supra note 5 , at 7.
} 
within the local political institutions in the Indies, currying favor where needed to gain local protection, full trading rights, and exemption from customs duties wherever possible. ${ }^{13}$ The Company's employees preferred "to bee [neutral] ... endevouring to doe our business, with a great deale of submission and not much charge." 14 Good rapport with local governments was thus imperative to early Company success. While the Dutch East India Company would require exclusive trading rights with the countries it visited, and enforce that exclusivity with military strength, "the [English Company] would build no forts ... and rarely land any guns. It deployed no troops in the East Indies and its objectives there would remain purely commercial.... [H] owever patriotically inclined, they served the Company, not the King, and they put profits . . before power." 15

Over time, the mission and practices of the Company changed and expanded to meet the challenges the company faced, embracing militarization and a governmental role in the Indies. The incessant search for new markets for English exports pushed the British government toward colonialism, and distinctions between "trade and flag" began to blur for the Company as well, making territorial acquisition nearly inevitable. ${ }^{16}$ The principal impetus for extending the Company's capabilities to include use of force and defense in the mideighteenth century came from continuing intense rivalries with other European trading powers such as the Dutch and later the French. Both of these competitor nations maintained a militarized presence in the East Indies, and both would use their superior power to gain advantage over the British. For example, on suspicion of inciting mutiny among the Dutch at their fort in Ambon, Company employees were brought unaware to the Dutch fort, imprisoned, and brutally tortured without immediately available recourse. ${ }^{17}$ The fear that the Dutch would overrun British factories, or blockade main factories to restrict return voyages to England, initially prompted the Company to move away from its

13. KeAY, supra note 2, at 18.

14. Bassett, supra note 5 , at 10 .

15. KeaY, supra note 2, at 34.

16. Peter Marshall, Economic and Political Expansion: The Case of Oudh, in 4 The East India Company, supra note 5, at 209; Rudrangshu Mukherjee, Trade and Empire in Awadh 1765-1804, in 4 The East India Company, supra note 5, at 218.

17. When word returned to England of the atrocities committed at Ambon, English outrage over the incident led to diplomatic reprisals against the Dutch; these reprisals, however, did little to help the tortured employees. KeaY, supra note 2, at 49. 
Managing the Expanding Mission of the World Bank 207

relatively pacifist tradition and invest in fortified settlements. ${ }^{18}$ The focus, however, remained on protecting trade, not gaining territorial supremacy.

The symbiotic relationship between the Company and the English Crown helped pave the way for the Company's militarization. The large profits the Company brought home to England from its trade in the East Indies, some of which became "donations" to the royal exchequer, went a long way toward managing the national debt, and many courtiers made handsome profits by investing in the company's voyages. ${ }^{19}$ The Crown was therefore only too happy to issue the Company a new charter in 1657 , giving the Company the right to fortify and colonize its establishments, and to transport settlers, stores, and ammunition to those colonies. ${ }^{20}$ Soon, the Company acquired the English settlement in Bombay in 1668 , thereby exercising governmental power for the first time in its history. ${ }^{21}$ The Company proceeded to set up a government, promulgate laws, attract settlers, and fortify Bombay to such a degree that its main rivals, the Dutch, were discouraged from attacking the new settlement. ${ }^{22}$ At that time, however, the espoused justification for owning territory was to supplement and protect revenue from trade. Indeed, when the Company's governors abroad became too extravagant with their military plans for Bombay, the directors in London wrote that "our business is to advantage ourselves by trade... and what government we have is but the better to carry on and support that trade." 23 Though its mission was undergoing radical change, the Company attempted to maintain its focus as a trade organization.

Adding to the pressure to militarize, wars originating in the homelands tended to play out in the East Indies as well. One example occurred when news of war between Britain and France reached India in 1744. Through their respective trading companies, France and Britain fought their war in India for fifteen years, disrupting each other's trade routes and attacking each other's cargoladen ships and factories. ${ }^{24}$ Though not officially soldiers fighting for the British

18. Bassett, supra note 5 , at 13.

19. Keay, supra note 2, at 142; K.N. Chaudhuri, The English East India Company in the 17th and 18th Centuries: A Pre-Modern Multinational Organization, in 4 The East Inda Company, supra note 5 , at 86.

20. KEAY, supra note 2, at 128.

21. Id. at 131.

22. Id. at 136.

23. Id.

24. Id. at 274 . 
Crown, the Company's merchants had tacit government approval for these actions. The Company thus became more and more a conduit for national expression, and through its close connections to its royal supporters, the Company eventually took up the "commercial imperialism" popular among rulers at the time. ${ }^{25}$ This shift in thought gave the Company the will and ability to militarize in response to prevailing conditions, and marked an important step in its evolution toward an administrative agency.

At the same time, the ruling Mughal dynasty in India went into decline and its formerly strict control over its empire began to decay, leaving a significant power vacuum in its wake. Insurgent local chieftains began the task of carving out their own lands independent of the Mughal emperor, and the British, by then exercising authority over much of the coast of India along the Bay of Bengal, found themselves in the center of political and military turmoil. ${ }^{26} \mathrm{New}$ fortifications and an expanded army were the Company's answer to the power struggles that threatened to disrupt its India trade. Thus, the decline in Mughal power coincided with a sudden ability on the part of the British to increase the Company's military power, leading to the development of large standing armies in the Company's service. ${ }^{27}$

In response to the machinations of other European trading companies and local warlords, the Company transformed itself into one of the "most effective military and territorial power[s]" in India, and in the mid-eighteenth century began to build warships in addition to trading ships. ${ }^{28}$ Before the FrenchEnglish war, the Company had garrisoned its forts with approximately 500 soldiers; after the war, that number had increased to several thousand. ${ }^{29}$ Though this increase in military strength came in response to a European threat, it was not long before the Company began to use strong-arm tactics against local governments when its profits were in danger and its traditional methods of

25. Id. at 142 .

26. Id. at 245 .

27. Marshall, supra note 12 , at 8 .

28. KEAY, supra note 2, at 267 . Note, however, that these warships were not initially captained by military men but by the merchants themselves; thus though the Company was more effective than other regional powers of the time, it lost many easy battles due to inexperience and its core essence of a merchant-run outfit. Id. at 287.

29. Marshall, supra note 12 , at 10. 
diplomacy were unsuccessful. ${ }^{30}$ Thus, the range of effective tactics at the Company's disposal multiplied considerably with the addition of fortifications, maritime power, and land-based forces. ${ }^{31}$

Moreover, the militarization of the Company's settlements pushed them to expand beyond mere centers of trade into centers of territorial power and influence, from which it was an easy step for these settlements to become an administrative power for the British Empire. ${ }^{32}$ By the late eighteenth century, the Company could take by force those commercial concessions it had only been able to ask for earlier. The Company now followed the lead of its European rivals, in this case the French, by usurping political control in key regions through the control of puppet governments dependent entirely upon the Company for military and economic support, thereby abandoning its earlier practice of local appeasement. ${ }^{33}$

With the governing structure and central purpose of a trading company, however, the Company was ill-equipped for sovereignty. Regardless, the Company found itself with territorial control of a large swathe of India called Bengal by the end of the eighteenth century. The Company, a trading company by design and culture, was, at its heart, not interested in territorial control as an end in itself. In fact, the constant use of force required to maintain the borders it controlled interfered significantly with trade and profit. Many times the Company would leave an enemy only pushed back but not defeated, thus inviting future

30. For example, when political instability in the local government of northern India threatened the Company's security and income from the region, the Company attempted first to coax political reform from within the local system, but when this course proved unfruitful, the Company did not hesitate to dispatch its military to force compliance with the reforms. Marshall, supra note 16 , at 197.

31. "Establishing and developing fortified settlements, utilizing maritime power, emphasizing the idea of fear, and the overt exercise of force, were all components in the evolution of an expansionary ideology among the English in India." I. Bruce Watson, Fortifications and the "Idea" of Force in Early English East India Company Relations with India, in 4 The East India Companv, supra note 5 , at 36 .

32. "The timely demonstration of controlled power, both when faced with threats from the 'country' powers of the hinterland and from European rivals on the seafront, helped in the growth of these settlements beyond mere centres of trade." S. Arasaratnam, Trade and Political Dominion in South India, 1750-1790, in 4 The EAST India Company, supra note 5, at 145.

33. KEAY, supra note 2, at 291 ("IThe French] had changed the rules of European involvement in India. For 150 years the Company had been endeavoring to appease the existing political hierarchy; in three years [the French] had simply usurped it. The English must either follow suit or leave the table."). 
trouble from the same quarters again and again. ${ }^{34}$ Moreover, use of force was extremely costly, and any money spent to protect its territory sapped the strength of the Company's trade in other more lucrative areas such as the burgeoning Chinese tea trade. ${ }^{35}$ Though Company servants in India claimed that Bengal would be highly profitable, the wealth never materialized due to local uprisings and widespread famine.

Eventually, the conditions in Bengal so drained the Company's finances that it was forced to approach the British government for a loan. The government took the opportunity to condition the loans in ways that led to future regulation and extensive governmental involvement in the internal affairs of the Company. ${ }^{36}$ Focused on the uprising in its American colonies, the British government did not have the substantial resources available to govern India, so instead of taking control of the territory away from the Company, the British government "restrained and reformed [the Company] until eventually it ceased to be either independent or mercantile and became instead a manageable and responsible administrative service....[U]nsurprisingly [this change's] implementation would prove slow, painful, and fraught with misery both for the Company and the people of Bengal." 37

Though it did not want control of Bengal outright, the British government used the company to gain control there without footing the bill or accepting responsibility for the dismal condition of the territory. Tales of the "misdemeanors and oppressions," "peculation and skulduggery" grew at home in England, intensifying the public desire for greater regulation of the Company and ensuring that it would not be allowed to work its problems out independently. ${ }^{38}$ An ulterior motive was also in play, namely that many new traders, and their political patrons, were eager to break the Company's monopoly on trade in the Indies, which included the coveted Chinese tea trade. ${ }^{39}$ In 1784, a bill was passed that sealed the Company's fate as a quasi-administrative agency of the government

34. Id. at 311 .

35. Id. at 362 .

36. Id. at 332 .

37. Id. at 363 .

38. Id. at 382,383 .

39. Ever since the Company showed that a profit could be made by British merchants in the East Indies, there were intermittent calls to break the monopoly granted by the Company's charter. See id. at 122, 451. 
by making the Company's Governor a Crown-appointed position. ${ }^{40}$ The Company, which began as an independent mercantile concern, had its rights reduced by 1813 to a partial monopoly of the China tea trade, and eventually lost its monopoly altogether by $1843 .{ }^{41}$ Having expanded beyond its capabilities as a trading company to take territorial control in India, the Company lost its effectiveness in trade, ceasing to exist in that capacity altogether.

\section{The World Bank}

The World Bank's history and organizational development have closely mirrored that of the Company, despite substantial differences in purpose and structure, in that both responded to political and ideological pressures from the developed world by over-expanding their missions. Founded in July 1944, the World Bank and the International Monetary Fund (IMF) were conceived at Bretton Woods to serve as "twin intergovernmental pillars supporting the structure of the world's economic and financial order." ${ }^{\prime 42}$ The World Bank is owned and directed by its member governments, which currently number 183 nations. ${ }^{43} \mathrm{It}$ is organized primarily as an investment bank dedicated to global development and poverty reduction. As such, it has redirected an estimated $\$ 500$ billion from industrialized countries to projects designed to "promote economic and social progress in developing countries by helping to raise productivity so that their people may live a better and fuller life." ${ }^{\prime 4}$ In fact, the World Bank is a group of three investment banks, each focused on a particular subset of clients in need of development assistance: the International Bank for Reconstruction and Development (IBRD), the International Development Association (IDA), and the International Finance Corporation (IFC). The IBRD attends to the needs of states that, though still needing assistance, can support competitive-rate interest payments on their World Bank loans; the IDA works with the poorest developing countries, lending at very low rates of interest; and the IFC focuses on assistance to the private sector. ${ }^{45}$

\footnotetext{
40. Id. at 390 .

41. Id. at $454,456$.

42. David D. Driscoll, The IMF And The World Bank: How Do They Differ? 1 (1988).

43. World Bank statistics are available at its website, at http://www.worldbank.org/about.

44. Adam Lerrick \& Allan H. Meltzer, Grants: A Better Way to Deliver Aid, in Quarterly International Economics Report 1 (Carnegie Mellon Gailliot Center for Public Policy, 2002), available at http://www.house.gov/jec/imf/grant.pdf; Driscoll, supra note 43, at 2.

45. Driscoll, supra note 42, at 3-4.
} 
While World Bank loans over the last fifty years have been instrumental in attracting other forms of foreign investment to emerging economies by providing adequate infrastructure to support such investment, private investment has significantly outstripped that of the World Bank. ${ }^{46}$ It is therefore somewhat surprising that the World Bank has garnered as much attention as it has recently, finding itself in the center of the current economic development debate. The Bank's evolution as a development institution, however, has consistently highlighted our constantly changing understanding of development, its underpinnings, and requirements for success. As an institution, the Bank lays bare the theories and policies of several decades of economic development, as well as setbacks in the development process.

As a result, the Bank is a primary battlefield for the creation of a new development policy that is manageable yet takes into account all that developed countries have learned about the nature of development thus far. The Bank is uniquely capable of promoting macroeconomic development, but must be wary of expanding its mission to include so many non-economic aspects of development that it loses effectiveness in meeting its objectives altogether, much as the East India Company expanded its mission too far to maintain its effectiveness as a trade entity.

\section{A. Changes in Development Theory and the Expanding Agenda of the World Bank}

At its inception, the World Bank's mission was simply stated and straightforward: to assist countries decimated by World War II in rebuilding productive capacity, and to improve the productive facilities of emerging countries in anticipation of future economic growth and international trade. ${ }^{47}$ Pursuant to this fundamental principle of promoting open trade, the World Bank initially offered loans intended to reestablish and improve elements of public infrastructure such as roads and power plants. ${ }^{48}$ The prevailing development theory of the time assumed that purely economic measures such as these were all that was necessary to promote open trade; politics, at least in theory, had no place in economic

\footnotetext{
46. See Jessica Einhorn, The World Bank's Mission Creep, 80 Foreign Afr. 22, 28 (2001) (noting that the World Bank has had to contend with the growth of private-capital flows that "were overshadowing development assistance and marginalizing the bank's role in all but the poorest countries"); see also, e.g., Lars Schoultz, supra note 1, at 571.

47. Schoultz, supra note 1 , at 538.

48. Einhorn, supra note 46 , at 23.
} 
development. ${ }^{49}$ This theoretical split between economics and politics was written formally into the articles of agreement of the IBRD: "The Bank and its officers shall not interfere in the political affairs of any member; nor shall they be influenced in their decisions by the political character of the member or members concerned. Only economic considerations shall be relevant to their decisions, and these considerations shall be weighed impartially." 50

The United States, however, as the most powerful member of the World Bank, often effectively imposed its own foreign policies upon Bank borrowers with silent, behind-the-scenes influence, leaving the theory of separation of economics and politics a fictional pretext in application. ${ }^{51}$ Thus, early and ongoing political pressure to influence developing countries' policies and ideology established the road toward expansion of the Bank's mission beyond pure economic infrastructure development.

Though the international community's initial focus was on economic development through the Bretton Woods institutions, the Cold War shifted that focus to the arena of national security, and the World Bank, along with development economics, received only low-level political interest. ${ }^{52}$ The Bank continued with its infrastructure development programs, however, and during the 1960s and 1970s learned much about the nature of development: Latin America fell prey to inflation and macroeconomic instability; the South Asian governments displayed the effects of significant state-led regulatory distortion of markets; and the Bank's experiences in Africa suggested that its focus on public infrastructure, without attention to human-resource development and social development, were not successful. In short, the World Bank "came to understand the importance of policy." 53

49. Schoultz, supra note 1 , at 538 .

50. Id.

51. Id. at 539; see also Ngaire Woods, The Challenges of Multilateralism and Governance, in $\mathrm{T}_{\mathrm{HE}}$ World Bank: Srructure and Policies 132, 134 (Christopher Gilbert \& David Vines eds., 2000) (demonstrating that the United States continues to wield considerable influence with the World Bank: "any sign of displeasure by the U.S. executive director has an almost palpable impact on the Bank leadership and staff, whether the signal is an explicit complaint or simply the executive director's request for information on a problem") [hereinafter Structure and Policies].

52. The obscurity of the National Advisory Council on International Monetary and Financial Policies, the U.S. executive branch committee responsible for U.S. dealings with the World Bank, in comparison to the political visibility of the National Security Administration, indicates the relative lack of interest in the World Bank and the issues it represented during the 1950 s and 60 s. Schoultz, supra note 1 , at 539,540 .

53. Einhorn, supra note 46, at 23. 
Corresponding to these new lessons in development, mainstream economics began openly to embrace politics, and the World Bank's lending practices began to be "justified ... in terms of the character and direction of the development process." 54 Thus, as one commentator notes, "by describing social goals as in puts rather than results, the bank cleared the path for a cumulative piling on of tasks over the decades, including issues of governance, participation by the poor, and anti-corruption." 55 Moreover, as knowledge about development grew, poverty reduction as a focus for development economics established itself firmly on the political economic map. ${ }^{56}$

The activism of the United States Congress in the 1970s further breached the wall between politics and economics, just as the British government mixed politics and trade with respect to the East India Company. During that decade, Congress made many attempts to influence U.S. policy toward the World Bank. Because, according to its charter the World Bank could not accept earmarked funds, Congress turned to legislation that restricted the decision-making ability of the U.S. executive directors when considering loans to governments engaged in activities to which Congress was opposed. ${ }^{57}$ For example, Congressional legislation from this period requires U.S. executive directors to vote against loans to countries that had expropriated U.S. property without compensation. ${ }^{58}$ Particularly significant for the World Bank's goals and mission, the 94th Congress also passed legislation that forces U.S. executive directors to oppose loans to developing countries with poor human rights records. ${ }^{59}$ The Congressional stance on human rights and World Bank assistance was reaffirmed in 1977, when the 95th Congress passed a bill linking the new U.S. contributions to the World Bank with the opposition of the U.S. executive directors to loans to human rights violators. ${ }^{60}$

54. Schoultz, supra note 1, at 537; Christopher L. Gilbert \& David Vines, The World Bank: An Overview of Some Major Issues, in Structure and Policies, supra note 51, at 10, 15.

55. Einhorn, supra note 46, at 24.

56. Ravi Kanbur \& David Vines, The World Bank and Poverty Reduction: Past, Present, and Future, in Structure and Policies, supra note 51, at 87, 89-90.

57. Schoultz, supra note 1 , at 546 .

58. Id. at 554-55.

59. By the end of the decade, the United States had voted against or abstained from votes concerning 112 loan proposals for human rights reasons. Id. at 559, 564 .

60. "[T]he United States in connection with its voice and vote ... shall advance the cause of human rights, including by seeking to channel assistance toward countries other than those whose governments engage in a consistent pattern of gross violations of internationally recognized human rights." This language indicates the blatant disregard for the anti-politicization language in Chapter IV of the IBRD articles of agreement set out earlier. Id. at 561. 
The injection of political concerns into World Bank decision-making through U.S. Congressional legislation indicated the power and persuasive ability of issue-oriented special interest groups in using the World Bank to create and modify development policy. ${ }^{61}$ The successful advocacy of these U.S. groups, particularly those concerned with human rights, opened the door for NGOs to influence World Bank development policy today, as their goals dovetailed with the World Bank's own experience in broadening development.

The 1980s saw a return to faith in openness and trade liberalization in developed countries, though World Bank rhetoric retained the concept of poverty reduction as the primary goal of economic growth and development. ${ }^{62}$ The World Bank also responded to critiques of its performance that pointed to a problem in rising income inequalities brought on by World Bank lending; as a result, the World Bank began to include in its mission the development of poverty-stricken rural and inner-city areas, and the education of the poor. ${ }^{63}$ At the same time, political interest in the World Bank continued to increase, especially in the United States, as the U.S. began to reduce its levels of bilateral foreign aid. ${ }^{64}$

The end of the cold war introduced a new wave of rapid changes in development theory and World Bank policy. The collapse of communist regimes in Eastern Europe led to the expectation of increased economic development based upon free markets and global interdependence; "[i]n short, hope was in the air." ${ }^{\prime 5}$ The world consequently took a closer interest in the World Bank and its role in championing the development of emerging economies and their entry into international commerce. 1989 marked the appearance of the Washington

61. "U.S. policy on an ample variety of economic issues is often the reflection of domestic political groups seeking to maximize their benefits or minimize their costs." Id. at 573.

62. Kanbur \& Vines, supra note 56, at 91-92.

63. Gilbert \& Vines, supra note 54, at 15-16.

64. Today, only five wealthy nations-Denmark, Sweden, Norway, Luxembourg, and the Netherlands-meet the U.N. target of spending $0.7 \%$ of their GNP on aid. Enough Talk, THE Economist, Nov. 24-30, 2001, at 14. "As its own bilateral aid program has shrunk, the United States has found the World Bank an especially useful instrument for projecting its influence in developing countries." Stephen Fidler, Who's Minding the Bank?, Foreign PoL'y, Sept.-Oct., 2001, at 40, 48. As an example, the portion of World Bank paid-in capital attributable to the United States is approximately $\$ 2$ billion, with a callable amount of $\$ 30$ billion that the United States does not have to contribute unless the World Bank defaults on its own bonds. Jose Angel Gurria \& Paul Volcker, The Role of the Multilateral Development Banks in Emerging Market Economies 10 (2001), at http://www.ceip.org/files/publications/pub_by_type.asp\#anchor.

65. Einhorn, supra note 46 , at 26. 
Consensus, encapsulating the development policy of the 1980 s with its purpose "to promote sound money and free trade, to free up domestic markets, and to encourage policy-makers to go home early and stop interfering with markets." ${ }^{66}$ The Washington Consensus attempted to distill the lore of developed countries' free market principles into ten precepts: fiscal discipline, redirection of public expenditure away from subsidies, tax reform, stabilization of interest rates, adoption of competitive exchange rates, trade liberalization, encouragement of foreign direct investment, privatization, deregulation, and enforcement of property rights. ${ }^{67}$

Despite this optimism, however, the adoption of free trade principles was not a smooth process, and the World Bank learned further lessons about development. The seductive nature of the free market ideology ensured its swift acceptance among newly developing countries, but it turned out to be a poor substitute for the all-inclusive ideology formerly communist states left behind. This problem was exacerbated by the fact that policy makers in developing countries, chafing at being told what to do, tended to implement only partially the changes advocated by the Washington Consensus and the World Bank. ${ }^{68}$ Moreover, the World Bank was struggling to cope with increased costs amid the rapid influx of countries requiring its assistance after the fall of the Soviet Union. ${ }^{69}$ These factors together led to another period of difficulty for the World Bank in the form of the Latin American debt crisis and the Asian financial crisis.

The World Bank emerged from these crises in the late 1990 s convinced that economic development cannot succeed without the support of "good" domestic policies in an increasing number of areas found to be interdependent with economic growth. ${ }^{70}$ Hence the development of the "Five I's of Economic Reforms," focusing development attention on international economic instability, investment, inequality, institutions, and ideology. ${ }^{71}$ Implicit in the new set of policy goals is the realization that poverty and the five I's must be tackled directly, not

\footnotetext{
66. Joseph E. Stiglitz, Introduction, in Structure and Policies, supra note 51, at 1.

67. Moisés Naím, Washington Consensus or Washington Confusion?, Foreing Pol'y, Spr. 2000, at 87,89 .

68. See id. at 90 .

69. See Gurria \& Volcker, supra note 64 , at 7.

70. "It is also clearer now that the recipe for prosperity has many ingredients and that their exact quantities, mix, and sequencing are not well known." See Naím, supra note 67, at 97.

71. Id. at $97-101$.
} 
collaterally through exclusive focus on indicators of economic growth. ${ }^{72}$ This rapid proliferation of World Bank interests led to a corresponding rise in the number of reforms thought necessary, similar to the manner in which the East India Company built up military capabilities in response to its acquisition of colonial powers. ${ }^{73}$ For example, in order to address economic instability and investment, the World Bank determined that in addition to macroeconomic policy recommendations, it would also stress an agenda calling for "anticorruption, effective corporate governance, banking transparency and independence, strong capital markets, and sufficient social safety nets." In short, the World Bank began to advocate that a strong legal system was key to successful economic development. ${ }^{74}$ This unprecedented expansion of World Bank goals and of its mission heralded the rise of conditionality, pursuant to which compliance with the World Bank's new agendas was a requirement of continued funding. In 1989, an average of 56 conditions were attached to each and every loan. ${ }^{75}$

The last several years have seen a continuation of the World Bank's trajectory in expanding its mission. Instead of sustainability of market reform, the current buzzwords are sustainability of democracy, building upon the theory devised in the last decade that "it [is] not as much what the Bank does, but to whom the Bank chooses to lend, that affects the success of adjustment." ${ }^{76}$ Consequently, the World Bank has built upon its initial legal reform efforts by working with recipient states to standardize their legal codes through the

72. For example, education and health improvements for the poor allow poor people to work harder and more efficiently, thereby increasing national productivity and spurring economic growth. The World Bank, it is argued, should directly focus upon education and health, in this example, rather than looking only to indicators of economic growth. See Kanbur \& Vines, supra note 55 , at $92-95$.

73. "The new data [from a crisis] would usually show that the main 'lessons' derived from previous crises missed some important element ... whose critical importance had been clearly illuminated by the most recent crisis. It would also show that more reforms would be needed." Naím, supra note 67 , at 91 .

74. See also Einhorn, supra note 45, at 29 (noting also that the World Bank has moved on to even more grand visions of development including "abolishing poverty, embracing global civil society, giving voice to the poor, and pursuing sustainable growth").

75. Gilbert \& Vines, supra note 54 , at 24.

76. Francisco H.G. Ferreira \& Louise C. Keely, The World Bank and Structural Adjustment: Lessons from the 1980s, in Structure and Policies, supra note 51, at 159, 174; see also Jonathan Isham \& Daniel Kaufmann, How Policies and Institutions Affect Project Performance: Microeconomic Evidence on Aid, Policies, and Investment Productivity, in Structure and Polici es, supra note 51, at 228, 257 (noting that where recipient states' policies are improving, financing tends to pay off). 
development of "best practices" in areas such as banking, accounting, and securities regulation. ${ }^{77}$ At the instigation of the World Bank president, James Wolfensohn, it has also involved representatives from NGOs, business, labor, religious, and women's groups, to name a few, in external dialogues about the direction development should take. ${ }^{78}$ This in turn has enlarged the cycle of World Bank mission growth, bringing the World Bank into contact with such diverse and disparate issues as biodiversity, ozone depletion, narcotics, corruption, and crime. ${ }^{79}$ The pressure on the World Bank to take on new issues does not look like it will lessen in the near future; already, the United States has urged World Bank assistance, without regard to the suitability of recipient economic or democratic policies, to those developing countries that offer it help in its war against terrorism. ${ }^{80}$ By going down a similar path, the East India Company became little more than a governmental arm of the British empire.

\section{B. The Current Debate Over The World Bank Mission}

It has been urged several times that the World Bank disband or scale back its programs, but "[u]nlike old soldiers, international institutions never fade away...[a]ll attempts to downsize them end up by making them bigger." ${ }^{81}$ The debate has thus shifted to merely discussing the scope of the World Bank's future development policies and goals. The current debate reveals two camps: those who believe that the World Bank should continue to expand its mission as it has, and those who believe that it is time for the World Bank to return to the basics of aid for purely economic purposes.

77. Einhorn, supra note 46, at 29-30.

78. Fidler, supra note 64, at 45.

79. See Einhorn, supra note 46, at 32. Interestingly, the World Bank is also being pulled back into old mission haunting grounds in the form of "postconflict reconstruction." Id.

80. Bribing Allies: The IMF and the World Bank Become Part of America's Anti-Terrorist Arsenal, The Economist, Sept. 29, 2001, at 71. In a recent speech given to the World Economic Forum, U.S. Secretary of State Colin Powell said "terrorism really flourishes in areas of poverty, despair, and hopelessness, where people see no future... We have to show people who might move in the direction of terrorism that there is a better way." N.Y. TIMEs, Feb. 2, 2002, (Late Edition-Final) at A1. At the same event, Philippine President Gloria Macapagal remarked, "Where there is great poverty, you will also have the breeding ground for the recruits, for the evil ideologues who spread terror." L.A. Times, Feb. 2, 2002, Part A, Part l (Home Edition), at 3. Given the centrality of poverty reduction to the World Bank's agenda, it is clear that the United States expects the World Bank to take a strong role in fighting terrorism.

81. Alan Walters, Do We Need the IMF and the World Bank? 8 (1994). 
Proponents of the World Bank's current expansionary direction believe that a holistic approach to development is necessary for success in reducing poverty. They cite sobering statistics: for example, only one in three World Bank projects succeeds in improving the standard of living in the target country ${ }^{82}$ To remedy this, these critics believe that the World Bank must expand its reach beyond macroeconomic policy reform and include promotion of effective institutions to support such reform, especially in the areas of labor-force education, efficient telecommunications infrastructure, and a reliable justice system. ${ }^{83}$ Inherent to the holistic approach, according to Wolfensohn, is the notion that the World Bank "cannot adopt a system in which the macroeconomic and financial is considered apart from the structural, social and human aspects, and vice versa...." ${ }^{84}$ In short, all the causes of poverty should be addressed, not just its macroeconomic symptoms ${ }^{85}$ and the World Bank must advocate supplanting indigenous practices with the theories of developed countries in an ever-increasing number of areas of governance.

Corruption and its role in underdevelopment is also an important topic for holistic proponents. Those who follow the holistic approach believe corruption to be at the very core of underdevelopment, because corrupt governments funnel aid money away from efficient projects into politicians' pockets. ${ }^{86}$ It is a small step from this connection to the conclusion that the current method of attaching conditionalities to World Bank loans is ineffective and allows corruption to undermine the World Bank's initiatives. Moreover, the more harsh such conditions become in an attempt to enforce efficiency, the more the World Bank is seen, especially in the developing world, as the advocate of "new economic colonialism." "Proponents of the holistic approach, therefore, often suggest a shift to a system of "democratic pluralism," whereby the World Bank would not mandate the steps a developing country need follow to qualify for aid, but merely open a dialogue with the country, outlining several alternatives from which to choose. The World Bank would not express an opinion on which was the optimal solution, and would not interfere with the country's selection process even if

\footnotetext{
82. Lerrick \& Meltzer, supra note 44, at 1 .

83. Naím, supra note 67 , at 93 .

84. Id. at 96.

85. Christopher L. Gilbert et al., Positioning the World Bank, in Structure and Policies, supra note 51 , at 39,41 .

86. Stiglitz, supra note 66 , at 3.

87. Id. at 4 .
} 
the country chooses the economically inferior path to development. ${ }^{88}$ Those who favor the holistic approach also advocate closer relationships with NGOs with expertise in infrastructure vital to development that does not involve economic policies.

On the other side of the debate, critics of the World Bank's current direction call attention to what Jessica Einhorn has called a "mission creep," the World Bank of over-reaching its clear and manageable mission of economic development reform. Though these critics admit that development solutions cannot be limited to macroeconomic reform, they find that the World Bank has become a one-stop shop for all the development goals of its members, and now for NGOs' goals as well. Thus, the World Bank's approach to development has been described as "faddish as skirt lengths and tie widths" and "softheaded" because it has shifted away from a purely analytical approach. ${ }^{91}$ The proliferation of World Bank objectives has caused critics to worry that the scope of the World Bank's engagement in development has become too diffuse, thereby reducing its focus on its primary objective of raising the per capita income in developing countries. ${ }^{92}$

Critics also insist that the World Bank's assistance and goals have become too complex to be readily useful to developing countries. ${ }^{93}$ Indeed, they suggest that it is also too complex for the World Bank itself to manage: "[I]ts mission has become so complex that it strains credulity to portray the bank as a manageable organization. The bank takes on challenges that lie far beyond any institution's operational abilities." ${ }^{94}$ Like the East India Company, which faced political pressures in its declining years, the World Bank also attracts many constituencies that wish to control it because it has acquired so much knowledge about

88. Id.

89. See generally Einhorn, supra note 46.

90. Naím, supra note 67, at 87; see also Fidler, supra note 64, at 45 ("Critics charge that, under pressure from NGOs and other interest groups... Wolfensohn has surrendered the World Bank's intellectual integrity, rushing to embrace the latest fads in development thinking regardless of their substantive merit.").

91. Fidler, supra note 64 , at 41.

92. Id. at 47.

93. "Policy makers who had hitherto never heard of the long bond suddenly had to scramble to understand the impact of debt-equity swaps on their country's fiscal account and their link to foreign portfolio flows." Naím, supra note 67 , at 92.

94. Einhorn, supra note 46 , at 22. 
development. Broadening the World Bank's focus, it is argued, would only enhance this effect. ${ }^{95}$

Lastly, the critics also contend that developing countries are worse off in several ways when the World Bank pursues an expanded mission. First, the introduction of increasing numbers of societal and economic reforms required for development invokes frustration in developing countries because in essence the World Bank is creating a paradox: the Bank will only offer development assistance when a country is developed. ${ }^{96}$ Second, the investment required for the World Bank to become an expert in all the areas effecting development, not to mention related administrative costs, would raise developing countries' cost of doing business with the World Bank considerably. ${ }^{97}$ Third, the continually changing mix of development policies that the World Bank pushes on developing countries only fosters suspicion of and uncertainty in the development process. ${ }^{98}$ Lastly, some critics worry that despite new dialogue with NGOs, the voices of developing countries themselves are still not being heard, and their views on the process are being ignored ${ }^{99}$ Thus critics worry that forced wholesale substitution of free trade policies occurs without support from local governments, and therefore will not assist development effectively.

\section{Solutions}

Both critics and proponents of the holistic approach to development have suggested policy changes with respect to World Bank activity. I discuss three such theories below.

A staunch critic of the World Bank's current mission expansion, Jessica Einhorn proposes several changes that would bring the World Bank closer to its original mission and goals, but re-oriented toward the economic issues of today. She suggests that national finance ministers should be given a greater role in providing the World Bank with direction and reorganization. ${ }^{100}$ The World Bank's "core competencies" in economic reform, based on years of experience

\footnotetext{
95. Id. at 31 ,

96. Naím, supra note 67 , at 96 ; see also Einhorn, supra note 46, at 31 .

97. Higher interest rates on Bank loans would have to be charged to cover these extra costs.

Fidler, supra note 64, at 48; see also Gurria \& Volcker, supra note 64, at 7.

98. Naím, supra note 67 , at 91.

99. Woods, supra note 51 , at 150.

100. Einhorn, supra note 46, at 34.
} 
and knowledge, should be enhanced and designated as the primary "product" the World Bank has to offer. ${ }^{101}$ The World Bank should moreover scale back its direct involvement with private enterprise in developing states, such as the provision of micro-credit services, and focus its research ability on the "wholesale" approach to development through proposing public-sector economic reform. ${ }^{102}$ Most importantly, Einhorn notes that for the World Bank to be most effective in its lending, it must acknowledge that private capital flows have far outpaced public aid, and make certain that its own lending policies complement and enhance the private investment process. ${ }^{103}$

Einhorn's proposition restores the original macroeconomic focus of the World Bank's mission, but still requires the World Bank to at least recognize the new theories of development harvested from its fifty years of experience. It does not directly respond, however, to the problem identified by supporters of a more holistic approach to aid, namely that traditional remedies for under-development have not delivered an adequate success rate. Einhorn argues that the recent dismal record of World Bank projects is due to their unmanageable scope. The scope became unmanageable, however, precisely because of the realization that macroeconomic policy reform alone cannot bring about lasting change, much like the East India Company found that to effectively maintain its trade in the Indies it had to expand its mission to include colonial rule. Einhorn's suggested retreat from addressing the myriad other factors of development leaves a gap in effective aid distribution that must then be filled by other intergovernmental and nongovernmental agencies, or individual governments. If history is any indication, it is unlikely that such an organization or government would rise to the task, and even less likely that it would do so effectively. Moreover, Einhorn seems to envision many agencies working in concert, each responsible for a factor of development relating to its own individual expertise. The chances of a bureaucratic bog developing are high, and there are no assurances that developed countries will be willing to spend more on aid through other agencies.

Adam Lerrick and Allan Meltzer advocate scrapping the World Bank's loan program altogether in favor of a system of grants, especially for the poorest client states. ${ }^{104}$ Instead of giving developing countries loans, saddled with condi-

101. Id.

102. Id.

103. Id. at 34-35.

104. See generally Lerrick \& Meltzer, supra note 44. 
tionalities, that so rarely produce effective results, the World Bank would issue grants for specific projects, expecting the target country to co-pay a portion of the project cost. They argue that the use of grants would reduce the inhibitive effect of corruption on the aid process because the World Bank would transfer the grant money only upon receiving an independent audit confirming that the project has met certain concrete criteria and objectives. ${ }^{105}$ These grants would not be any more costly to the World Bank or its developed member governments than traditional loans; because interest rates on current loans to very poor client states are so low, the client states effectively are given a gift of approximately the same proportion as the proposed grant. ${ }^{106}$ The authors argue that grants would also eliminate a source of debt-load for poor countries, because the money is a gift, payable when observable progress is made in the specified objectives of the project. They predict an increase in efficiency of World Bank projects without additional expense, and, unlike Einhorn, they encourage the World Bank to institute "a career change from an elegant banker dispensing large volumes of largesse to a development agency with a gritty and demanding workload." 107

Though on its face Lerrick and Meltzer's idea seems to address the issue of corruption and inefficiency effectively, it is subject to possible politicization. It is not clear who would determine the success criteria applied to grants nor how stringent they would be; thus, existing loan conditionalities, detested by developing countries and derided by developed countries as ineffectual, may merely be renamed as success criteria for grants. Additionally, though an independent audit to determine success sounds like an impartial solution, the authors do not suggest who these independent auditors should be. NGOs have their own agendas, as would members' finance ministers, and so would politicize the process through their involvement.

Christopher Gilbert and David Vines introduce yet another possible direction for the World Bank: that it transform itself into a "Knowledge Bank." 108 This approach is the least directly involved with client state affairs of the three drawn out here, and expands on Einhorn's suggestion that the World Bank focus exclusively on areas of its expertise. The authors, however, define the World Bank's expertise more broadly, to include many of the non-economic

105. Id. at 1 .

106. See id. at 4.

107. Id. at 5-6.

108. Gilbert \& Vines, supra note 54 , at 10. 
goals and factors of development that the World Bank has attempted to research and address in recent years. Because the World Bank is still in a position to give more independent advice than professional consultants, more pragmatic advice than academics, and more comprehensive advice than NGOs, it should restructure itself to focus on sharing and disseminating that information in countries that need it. ${ }^{109}$ The authors also contend that a less hands-on approach to aid is now possible because, since the end of the Cold War, the World Bank can afford to disengage from countries that do not follow its advice. ${ }^{10}$

This argument seems to provide an acceptable middle ground between addressing the interrelated problems of development and focusing on the World Bank's core competencies, but would be difficult to implement. The World Bank, though a more disinterested party than the member governments themselves, is still a highly politicized institution, and so would have great difficulty in disengaging and becoming a repository of knowledge to be tapped at will by developing governments. The World Bank is especially tied to U.S. interests, particularly now that the war on terrorism has pushed the United States to exert pressure on the World Bank to give special aid support to its allies.

\section{Conclusion}

Though expanding the goals and methods of the East India Company was a necessary and in some instances beneficial development to protect its trade and profits, in the end, over-expansion beyond manageable levels destroyed the East India Company's ability to function as a trading company in India at all. Pressured by the British government's desire to become a colonial power, and by the ideologies of the developed world that advocated direct replacement of local rule with European rule, the East India Company reached beyond its mission and capabilities to play an administrative role in India. Though the World Bank is an institution with a different constitution, mission, and political economic environment, the East India Company's example teaches moderation for the World Bank as it now faces a potentially similar situation of expansion beyond its realistic capabilities.

The East India Company responded to its political and economic surroundings, heavily influenced by imperialism, by expanding its military and territorial

109. Id. at $29-30$.

110. Id. 
holdings, but found that it could not maintain effective trading and govern India at the same time. The World Bank, too, has responded to liberal political economic theory by expanding its ministrations to include justice system reforms, human rights requirements, and many more factors key to development. It may find, however, that over-expansion to address all the elements of development limits its own effectiveness in the war against poverty. Moreover, the comprehensive application of "our way or nothing," carried over in modified form from colonial days, may not be the most effective way to assist resistant developing countries.

To avoid a similar fate to that of the East India Company, the World Bank must know and respect its institutional limits. It can, however, become an independent and international source of leadership by providing theory and insight as a kind of Knowledge Bank, while at the same time fostering the development of institutions such as micro-banks that directly influence and improve the daily lives of citizens in developing countries. Its Knowledge Bank capabilities should not be limited to macroeconomic policy reform, but, as Gilbert and Vines suggest, include information the World Bank has gleaned from its many years of experience, and go a step farther to develop more research and advice concerning reforms on a scale that help but do not intimidate the poor who must use them, such as small-claims courts and government-respected property rights." ${ }^{11}$ Thus the World Bank would become a genuine source for development theory, suggesting but not forcing change. Even though indigenous practices may be corrupt or economically inferior according to the latest development theories, the World Bank is likely to have far better success by allowing developing countries to make the choices themselves based on suggested practices, allowing pressure to make those changes to come from private investment and increased trade opportunities.

Some excuse the World Bank's "mission creep" because governments have not come up with a better solution for the complex problem of providing effective development assistance. ${ }^{112}$ Unfortunately, this reaction allows the developed world to ignore or deny responsibility for the problems the World Bank has been facing, and delays a search for a more viable solution. Better to accept the natural limits of the World Bank as an institution, and embrace a realistic division of labor between the World Bank and other more nimble and gritty organizations and private entities that can better handle affairs at the action level.

111. See generally Now, Think Small, The Economist, Sept. 15, 2001, at 40, 42.

112. See Gurria \& Volcker, supra note 64, at 5-7. 
